\title{
The Effects of Zinc Oxide Nanoparticles on Enzymatic and Osmoprotectant Alternations in Different Moringa peregrina Populations Under Drought Stress
}

\author{
Leila Foroutan', Mahmood Solouki ${ }^{*}$, Vahid Abdossi ${ }^{1}$, Barat Ali Fakheri ${ }^{2}$ \\ 'Department of Horticultural Science, Science and Research Branch, Islamic Azad University, Tehran, Iran \\ ${ }^{2}$ Department of Plant Breeding and Biotechnology, Faculty of Agriculture, University of Zabol, Zabol, Iran
}

\author{
*Correspondence to \\ Mahmood Solouki, Department \\ of Agronomy and Plant \\ Breeding, University of Zabol, \\ Iran. \\ Tel: +98912109 7826; \\ Fax: +9854222267 62; \\ Email: \\ mahmood.solouki@gmail.com
}

Received April 26, 2018 Accepted August 7, 2018 Published online December 31,2018

\begin{abstract}
Introduction: Moringa peregrina (Forssk.) Fiori as a desert tree has economic, nutritional, and medicinal properties, and is constantly encountered with drought stress. In addition, the role of zinc oxide nanoparticles ( $\mathrm{ZnO}-\mathrm{NPs}$ ) in regulating the drought stress which induces biochemical processes is uncertain in this plant. Therefore, this study aimed to investigate the biochemical alternations, namely, enzymatic and osmoprotectant which are induced by ZnO-NPs in ten populations of $M$. peregrina under drought stress.

Materials and Methods: Moringa peregrina seeds were collected from southeast of Iran in 2014. The young plants were exposed to drought stress by withholding irrigation (until $50 \%$ filed capacity [FC]) 40 days after germination followed by spraying 0 (as control), 0.05 , and $0.1 \%$ of the $\mathrm{ZnO}$ NPs.

Results: The alternations of $\mathrm{Na} / \mathrm{K}$ ratio, enzymes activities, and osmoprotectant content varied under drought stress depending on the M. peregrina populations. Generally, drought stress significantly enhanced peroxidase (POD) and polyphenol oxidase (PPO) activities, as well as proline content in untreated plants. Further, the $\mathrm{Na} / \mathrm{K}$ ratio and carbohydrates content significantly decreased under the drought stress. Furthermore, ZnO-NP treatment significantly enhanced POD and PPO activities, as well as proline and carbohydrates content under both well-watered $(100 \%$ FC) and drought stress conditions ( $50 \%$ FC), and at the concentration of $0.05 \%$ rather than $0.1 \%$, $\mathrm{ZnO}-\mathrm{NPs}$ was more effective.

Conclusion: Overall, $\mathrm{ZnO}-\mathrm{NP}$ treatment could effectively improve the drought tolerance by enhancing the enzymes activities and osmoprotectant content in different $M$. peregrina populations under drought stress. Therefore, foliar application of ZnO-NPs at $0.05 \%$ concentration could be a recommended treatment for growing different $M$. peregrina populations under drought stress conditions.

Keywords: Antioxidant enzymes, Osmoprotectants, Peroxidase, Proline, ZnO-NPs
\end{abstract}

\section{Introduction}

Moringa peregrina (Forssk.) Fiori, also known as horseradish tree, is a plant with economic and medicinal importance. The leaves are rich sources of various biomolecules (proteins), nutrients (amino acids), and natural antioxidants (vitamins $\mathrm{A}$ and C). In addition, the seed kernel contains high-quality oil with the inflorescences being used to feed the livestock. ${ }^{1,2}$ The plant grows in many areas of the world like Northeast Africa and Southwest Asia. The cultivation of medicinal plants has recently increased due to their enormous beneficial effects on health and nutrition industries. ${ }^{3}$
Accordingly, cultivation of $M$. peregrina has continuously extended in Iran. ${ }^{1}$

Totally, about one-third of the land on the earth belongs to the arid and semi-arid areas. Further, studies on global climate change predicted that the increasing frequency and duration of drought periods in the world are facing problems with plants cultivation in the drought stress. ${ }^{4,5}$

Drought is major abiotic stress which substantially limits the growth, morphogenesis, nutrients balance, and biochemical and physiological processes of the plants. ${ }^{5}$ Furthermore, oxidation of cellular biomolecules by means of various

(c) 2018 The Author(s); Published by Zabol University of Medical Sciences. This is an open-access article distributed under the terms of the Creative Commons Attribution License (http://creativecommons.org/licenses/by/4.0), which permits unrestricted use, distribution, and reproduction in any medium, provided the original work is properly cited. 
reactive oxygen species (ROS) like $\mathrm{O}_{2}^{-}$, singlet oxygen $\cdot \mathrm{O}_{2}, \cdot \mathrm{OH}$, and $\mathrm{H}_{2} \mathrm{O}_{2}$ ultimately leads to deranged cellular functions. ${ }^{6}$

To keep a steady ratio between the ROS production and removal, and consequently to relieve the damage related to the drought stress, plants evolved appropriate mechanisms such as stomata regulation, osmotic adjustment, and antioxidative defenses including enzymatic and nonenzymatic antioxidant systems.?

Antioxidant enzymes such as peroxidase (POD), polyphenol oxidase (PPO), superoxide dismutase (SOD), ascorbate peroxidase (APX), catalase (CAT), and glutathione reductase (GR) are the "first line of defense" against the ROS. The POD, among others, is a cell-wall located anti-oxidant enzyme which promotes its function through iron-containing heme core. Moreover, it is the main cellular component catalyzing the $\mathrm{H}_{2} \mathrm{O}_{2}$ detoxification in the cells and a major enzyme scavenging the $\mathrm{H}_{2} \mathrm{O}_{2}$ in chloroplasts produced from $\mathrm{O}_{2}^{-}$catalyzed by the superoxide dismutase. ${ }^{8}$ Similarly, the PPO is an enzyme which oxidizes some phenols to chinone. This enzyme is attributed to the biosynthesis of the alkaloids under biotic and abiotic stress conditions. ${ }^{9}$ The activity of enzymatic antioxidant defense systems can be variably suppressed when exposed to drought stress depending on the duration and intensity of the stress, genotypic variability, and crop developmental stage. ${ }^{10}$

Accumulation of different active ions, sugars, and organic compounds such as proline and carbohydrates plays a crucial role in cell osmoregulation and osmoprotection during the drought condition. Proline is an essential cytosolute regulating osmotic balance within the cells. In fact, proline executes its function by augmenting cellular anti-oxidative components, as well as preserving membrane and cellular structures and functioning as an oxygen radical scavenger. ${ }^{11}$ Additionally, it promotes some actions within the cell cytoplasm without interfering with cellular structure and metabolism. ${ }^{12}$

Drought stress can change the carbohydrate content within the plant tissues. Moderate, intense, and severe water deficits can lead to elevation, preservation, and reduction of soluble sugars in rapeseed (Brassica napus), respectively. ${ }^{13}$ In addition, based on their primary function as carbon and energy resources, carbohydrates are vital in maintaining the function of photosynthetic machinery within the cells. This is mainly triggered by regulating the cellular osmotic capacity and preserving the intracellular water. ${ }^{14}$

Micronutrient fertilizers are suggested as potential agents which increase the tolerance of plants to drought stress. By conserving membrane integrity and cellular potassium content, zinc $(\mathrm{Zn})$ is essential in regulating the stomatal function by inducing the stomatal closure and preventing the transpiration in plants under waterdeficit conditions. ${ }^{15}$ The $\mathrm{Zn}$ has important functions in the synthesis of auxin, as well as biochemical reactions required for the formation of carbohydrates. ${ }^{16}$ Further, it is revealed that $\mathrm{Zn}$ reduces the ROS production and increases the activity of enzymatic antioxidant systems such as the POD. ${ }^{17}$ Therefore, the $\mathrm{Zn}$ has a protective role in plant survival during the drought conditions. The $\mathrm{Zn}$ deficiency is a widespread micronutrient dysregulation in plants throughout the arid and semi-arid regions necessitating the $\mathrm{Zn}$ supplementation in these regions. ${ }^{18}$

Currently, the use of nanomaterials such as zinc oxide nanoparticles (ZnO-NPs) has expanded. Nanotechnology is now a revolutionary science increasing the application of nanoparticles in every field of science including agriculture, medicine, food, and biological and pharmaceutical applications. The sudden rise in the demand for the $\mathrm{ZnO}-\mathrm{NPs}$ is largely related to their higher efficiency compared to the conventional $\mathrm{ZnO}^{19}$

To our knowledge, no studies have been conducted to understand the physiological response of medicinal plants including $M$. peregrina to the $\mathrm{ZnO}-\mathrm{NPs}$ foliar use under the drought condition. Therefore, the present study sought to evaluate the effect of $\mathrm{ZnO}$-NPs on the physiological responses and antioxidant enzyme activities in different $M$. peregrina species under the drought stress.

\section{Materials and Methods}

Plant Materials and Growth Conditions

This study was performed in Agricultural Faculty of Sistan and Baluchestan University, Zahedan, Iran (latitude of $29^{\circ} 27^{\prime} 34^{\prime \prime} \mathrm{N}$, longitude of $60^{\circ} 51^{\prime} 10^{\prime \prime} \mathrm{E}$, altitude of $1385 \mathrm{~m}$, mean annual temperature of $18.3^{\circ} \mathrm{C}$, and an annual rainfall of $72 \mathrm{~mm}$ ) in a greenhouse during the growing season of 2014. The seeds of the ten M. peregrina species were collected from different regions of Sistan and Baluchestan province located in the southeast of Iran. Damaged parts of the plants and any other impurities (i.e., wood, leaves, stones, and dust) were removed. The seeds were then stored within black plastic bags and labeled. The locations and conditions regarding the arid and semi-arid climate are presented in Table 1.

The surfaces of the seeds were cleaned using $0.5 \%(\mathrm{v} / \mathrm{v})$ sodium hypochlorite and treated with benomyl solution for 30 minutes at $24^{\circ} \mathrm{C}$, and then rinsed three times with sterilized deionized water (DW). At least 20 seeds were placed in each $9-\mathrm{cm}$ petri dish covered by sheets of moistened filter paper and were kept in a germination chamber 12 hours light cycle at $25^{\circ} \mathrm{C}$. After germination, the seedlings were translocated to a growth chamber for 2 weeks at room temperature, $70 \%$ relative humidity with a 12 hours light cycle and daily access to water. Later, the young plants were sown in plastic pots $(30 \mathrm{~cm}$ height and $20 \mathrm{~cm}$ diameter) filled with sterilized steam containing organic horizon soil (black soil), clay horizon (red soil), and washed sand $(3: 1: 1, \mathrm{v} / \mathrm{v} / \mathrm{v})$. They were exposed to drought stress and $\mathrm{ZnO}-\mathrm{NP}$ treatment 40 days after the germination.

Before the treatments, the field capacity (FC) of the 
Table 1. Geographical Location of 10 Moringa peregrina Populations in Sistan and Baluchestan Province

\begin{tabular}{|c|c|c|c|c|}
\hline Population Number & Positions & Location of Collected Seeds & Latitude & Longitude \\
\hline 1 & Nikshahr & Konardan & $29^{\circ} 16^{\prime} 69^{\prime \prime} \mathrm{N}$ & $21^{\circ} 79^{\prime} 56^{\prime \prime} \mathrm{E}$ \\
\hline 2 & Nikshahr & Keshik & $29^{\circ} 13^{\prime} 84^{\prime \prime} \mathrm{N}$ & $23^{\circ} 27^{\prime} 94^{\prime \prime} \mathrm{E}$ \\
\hline 3 & Nikshahr & Shegim & $29^{\circ} 29^{\prime} 04^{\prime \prime} \mathrm{N}$ & $21^{\circ} 87^{\prime} 17^{\prime \prime} \mathrm{E}$ \\
\hline 4 & Nikshahr & Desk & $29^{\circ} 17^{\prime} 75^{\prime \prime} \mathrm{N}$ & $21^{\circ} 92^{\prime} 40^{\prime \prime} \mathrm{E}$ \\
\hline 5 & Nikshahr & Nesfuran & $29^{\circ} 18^{\prime} 55^{\prime \prime} \mathrm{N}$ & $78^{\circ} 40^{\prime} 95^{\prime \prime} \mathrm{E}$ \\
\hline 6 & Fanuj & Girls Seven & $29^{\circ} 19^{\prime} 72^{\prime \prime} \mathrm{N}$ & $75^{\circ} 26^{\prime} 06^{\prime \prime} \mathrm{E}$ \\
\hline 7 & Fanuj & Tange Fanuj Entrance & $29^{\circ} 38^{\prime} 89^{\prime \prime} \mathrm{N}$ & $76^{\circ} 27^{\prime} 30^{\prime \prime} \mathrm{E}$ \\
\hline 8 & Fanuj & Tange Fanuj & $29^{\circ} 35^{\prime} 68^{\prime \prime} \mathrm{N}$ & $76^{\circ} 29^{\prime} 73^{\prime \prime} \mathrm{E}$ \\
\hline 9 & Fanuj & Madohi Village & $29^{\circ} 29^{\prime} 45^{\prime \prime} \mathrm{N}$ & $76^{\circ} 26^{\prime} 47^{\prime \prime} \mathrm{E}$ \\
\hline 10 & Fanuj & Dahan Village & $29^{\circ} 15^{\prime} 45^{\prime \prime} \mathrm{N}$ & $75^{\circ} 39^{\prime} 26^{\prime \prime} \mathrm{E}$ \\
\hline
\end{tabular}

medium was measured by filling 3 pots with water. The posts were covered with plastic to prevent evaporation. This was continued for 24 hours to drain. Then, the moisture content of the soil samples was determined according to Kramer and Boyer ${ }^{20}$ Next, the seeds were exposed to drought stress 40 days post germination. All the pots were kept at 100\% FC (well-watered) and 50\% FC (drought condition) during the study.

Seven days after the drought stress, plants were sprayed with different concentrations of $\mathrm{ZnO}-\mathrm{NPs}$ (0 [as control], $0.05, \& 0.1 \%$ ) and a second $\mathrm{ZnO}-\mathrm{NPs}$ foliar was applied 1 week later. The sprays continued to completely render the leaves soaked with the excess solution ran off the leaves. The $\mathrm{ZnO}-\mathrm{NPs}$ were purchased from Iranian nanomaterials Pioneers Company. Plants were harvested at 30th day of the $\mathrm{ZnO}-\mathrm{NPs}$ spray and were further used for other analyses.

Measurements and Analyses

Sodium/Potassium Ratio

To measure sodium $(\mathrm{Na})$ and potassium $(\mathrm{K})$, leaf samples were initially washed thoroughly with tap water and then rinsed in DW. Then, fruit flesh samples were obtained and oven-dried at $70^{\circ} \mathrm{C}$ for 48 hours. The fruits were powdered and then passed through a forty-mesh sieve. A portion of the fine powder $(2 \mathrm{~g})$ was turned to ashes in a furnace at $550^{\circ} \mathrm{C}$ for 4 hours. Next, $10 \mathrm{~mL}$ of $2 \mathrm{M}$ hydrochloric acid ( $\mathrm{HCl})$ was added to dissolve the ashes. The digested samples were passed through the filter paper (Whatman No. 40). Finally, the purified solution was used for $\mathrm{Na}$ and $\mathrm{K}$ analyses. The contents of $\mathrm{Na}$ and $\mathrm{K}$ were determined by flame photometric (Biotech Engineering Management Co. Ltd. the UK) method as described by Waling et al. ${ }^{21}$

Enzymes Assays

Spectrophotometry was employed for determining the POD activity according to Hung and Kao.22 To this end, fresh leaves (500 mg) were initially frozen (liquid nitrogen) and then transferred into $2 \mathrm{~mL}$ extraction buffer $(0.1 \mathrm{M}$ phosphate buffer, $\mathrm{pH}=6.8$ ). After centrifugation for 15 minutes at $13000 \mathrm{~g}$ of the homogenate, the enzyme activity was measured in the obtained supernatant by reading the absorbance at $470 \mathrm{~nm}$ (UV/Vis spectrophotometer, Bio-Rad, USA). Furthermore, the extinction coefficient [26.6 $\left(\mathrm{mmol} \mathrm{L}^{-1}\right)^{-1} \mathrm{~cm}^{-1}$ ] for tetraguaiacol was applied to calculate the enzyme activity. The result was expressed as $\mu \mathrm{M}$ tetraguaiacol formed per minute per mg protein $(\mu \mathrm{M}$ $\mathrm{mg}^{-1}$ protein $\mathrm{min}^{-1}$ ).

Moreover, the PPO activity was estimated according to Kar and Mishra ${ }^{23}$ with slight modifications. Briefly, 100 $\mu \mathrm{L}$ of the enzyme extract was added to $2800 \mu \mathrm{L}$ sodium phosphate buffer solution $(25 \mathrm{mM}, \mathrm{pH}=6.8)$ and 100 $\mu \mathrm{L}$ of $1 \mathrm{mM}$ pyrogallol. The blank consisted of $2900 \mu \mathrm{L}$ sodium phosphate buffer solution $(25 \mathrm{mM}, \mathrm{pH}=6.8$ ) and $100 \mu \mathrm{L}$ of the enzyme extract. Absorbance at the wavelength of $420 \mathrm{~nm}$ was considered as corresponding to the enzymatic activity. Finally, the PPO activity was expressed as $\mu \mathrm{M} \mathrm{mg}^{-1}$ protein $\mathrm{min}^{-1}$.

\section{Osmoprotectant Capacity of Zn-NPs}

Osmoprotectants are small molecules with minimum electrical conductance. At very low concentrations, these molecules are highly water-soluble with no cellular toxicity. Osmoprotectants are particularly important for the plants regarding tolerating the extreme osmotic conditions. Additionally, these osmoprotectants as the membrane stabilizers play a role in regulating the membrane permeability to water and avoiding intracellular dehydration. Proline is one of the main osmoprotectants, the content of which was determined by a colorimetric assay according to Bates et al. ${ }^{24}$ Briefly, fresh leaf samples (200 mg) were homogenized in an aqueous solution of (w:v) sulphosalicylic acid 3\%. The mixture of the plant extract with an acid ninhydrin and glacial acetic acid (2:2:2 ratios, respectively) was incubated at $100^{\circ} \mathrm{C}$ for 1 hour. The reaction was terminated on ice. In addition, the mixture was extracted using $4 \mathrm{~mm}$ of toluene generating a chromophore-containing toluene phase which was harvested. The absorbance was read at $520 \mathrm{~nm}$ using the toluene as blank to calculate the proline content by the 
following formula:

Proline $(\mu$ moles $/ \mathrm{g}$ of fresh weight material $)=[(\mu \mathrm{g}$ proline / $\mathrm{mL} \times \mathrm{mL}$ toluene $) / 115.5 \mu \mathrm{g} / \mu$ mole $] /$ [(g sample $) / 5]$

Soluble carbohydrates were then measured according to the method reported by Irigoyen et al. ${ }^{25}$ In sum, $2 \mathrm{~g}$ of fresh leaves were boiled in $10 \mathrm{~mL}$ of hot $95 \%$ ethanol for 2 hours at $80^{\circ} \mathrm{C}$. After cooling, the mixture was centrifuged at $9000 \mathrm{~g}$ for 15 minutes and then the supernatant was decanted. The $5 \mu \mathrm{L}$ of sulphuric acid (98\%) and $1 \mathrm{~mL}$ of phenol $(0.5 \%)$ were added to $1 \mathrm{~mL}$ of supernatant. Next, the soluble carbohydrates content was determined using a spectrophotometer (Bio-Rad, USA) at $625 \mathrm{~nm}$. The total soluble carbohydrates content was calculated by creating a standard curve using the glucose and expressed in $\mu \mathrm{g}$ $\mathrm{g}^{-1}$ FW.

\section{Statistical Analysis}

The statistical methods were conducted according to 3 -factors linear model based on a completely randomized design in triplicate. Data were analyzed by the analysis of variance (ANOVA) employing the SAS software, version 9.1). Further, the data were checked for normality and homoscedasticity using the Shapiro-Wilk test. The least significant difference (LSD) test at $P \leq 0.01$ was considered statistically significant.

\section{Results}

Changes Under the Drought Stress

$\mathrm{The} \mathrm{Na} / \mathrm{K}$ ratio reduced or enhanced in response to drought stress were dependent on the $M$. peregrina populations. Generally, as shown in Figure 1, the drought stress significantly $(P \leq 0.01)$ reduced the $\mathrm{Na} / \mathrm{K}$ ratio in the control plants $(0.00 \% \mathrm{ZnO}-\mathrm{NPs})$. The population number 10 demonstrated the highest changes in response to drought stress.

Based on the results provided in Table 2, POD and PPO

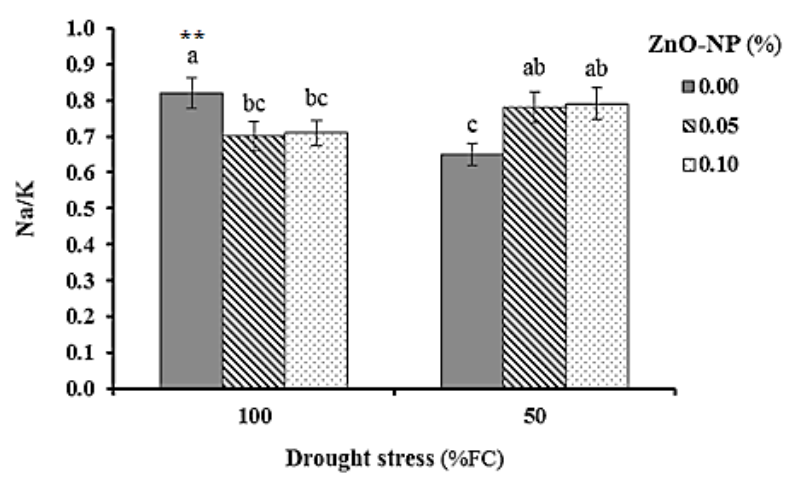

Figure 1. The $\mathrm{Na} / \mathrm{K}$ Ratio Changes of Moringa peregrina Under WellWatered (100\% FC) and Drought Stress (50\% FC) in Response to $\mathrm{ZnO}-\mathrm{NP}$ Treatments. The values are presented as the means $(\mathrm{n}=3) \pm$ standard errors. Different letters indicate a significant difference $(P \leq$ $0.01)$ according to the LSD test.

Table 2. Changes of Some Biochemical Parameters in Different Moringa peregrina Populations the Under Well-Watered (100\% FC) and Drought Stress (50 s\% FC) Conditions

\begin{tabular}{|c|c|c|c|c|c|c|}
\hline Drought Stress & Populations & $\mathrm{Na} / \mathrm{K}$ & $\begin{array}{c}\text { POD Activity } \\
\left(\mu \mathrm{mol} \mathrm{min}^{-1} \mathrm{mg}^{-1} \text { Protein }\right)\end{array}$ & $\begin{array}{c}\text { PPO Activity } \\
\left(\mu \mathrm{mol} \mathrm{min}^{-1} \mathrm{mg}^{-1} \text { Protein) }\right.\end{array}$ & $\begin{array}{c}\text { Proline } \\
\left(\mu \mathrm{mol} \mathrm{g}^{-1} \mathrm{FW}\right)\end{array}$ & $\begin{array}{c}\text { Carbohydrates } \\
\left(\mu G g^{-1} \mathrm{FW}\right)\end{array}$ \\
\hline \multirow{10}{*}{$100 \%$ FC } & 1 & $0.90 \mathrm{abc}^{*}$ & $0.054^{\mathrm{h}}$ & 0.039 m & $0.604 \mathrm{gh}^{\mathrm{gh}}$ & $33.45^{\mathrm{gh}}$ \\
\hline & 2 & 0.67 def & $0.053^{h}$ & $0.046^{\mathrm{jk}}$ & $0.576^{\mathrm{hi}}$ & $37.64^{\text {cdef }}$ \\
\hline & 3 & $0.77^{b c d}$ & $0.042^{j}$ & $0.052^{h}$ & $0.516^{j}$ & $32.46^{h}$ \\
\hline & 4 & $0.89 a b c$ & $0.054^{h}$ & $0.052^{h}$ & $0.583^{g h}$ & $35.51^{\mathrm{fgh}}$ \\
\hline & 5 & $0.91 \mathrm{abc}$ & $0.039 \mathrm{kl}$ & 0.042 & 0.582 gh & 38.37 cdef \\
\hline & 6 & 0.61 def & $0.037^{\prime}$ & $0.047^{\mathrm{ij}}$ & $0.610^{g}$ & $39.23^{c d}$ \\
\hline & 7 & $0.66^{\text {def }}$ & $0.047^{i}$ & $0.043^{\mathrm{kl}}$ & $0.523^{i}$ & $35.50^{\mathrm{fgh}}$ \\
\hline & 8 & 0.74 cde & $0.050^{i}$ & $0.050 \mathrm{hi}$ & $0.527^{i}$ & 38.93 cde \\
\hline & 9 & $0.70^{\text {def }}$ & $0.040^{j k}$ & 0.049 hi & $0.618^{g}$ & 38.81 cde \\
\hline & 10 & $0.53^{f}$ & $0.037 \mathrm{kl}$ & $0.035^{n}$ & $0.433^{k}$ & $35.67 \mathrm{fg}$ \\
\hline \multirow{10}{*}{$50 \%$ FC } & 1 & $1.03^{a}$ & $0.092^{a}$ & $0.062^{f}$ & 0.708 def & $36.32^{\text {cdef }}$ \\
\hline & 2 & 0.62 def & $0.084^{c}$ & $0.068^{e}$ & 0.72 de & $44.15^{a}$ \\
\hline & 3 & $0.73^{\text {cde }}$ & $0.059^{g}$ & $0.075^{d}$ & $0.843^{a}$ & $37.70^{\text {cdef }}$ \\
\hline & 4 & $0.94^{\mathrm{ab}}$ & $0.074^{d}$ & $0.094^{b}$ & $0.871^{b}$ & $38.03^{\text {cdef }}$ \\
\hline & 5 & 0.60 def & $0.067^{e}$ & $0.062^{f}$ & $0.765 b c$ & $43.08 \mathrm{ab}$ \\
\hline & 6 & $0.70^{\text {def }}$ & $0.054^{h}$ & $0.068^{e}$ & $0.768^{b c}$ & $40.76^{b c}$ \\
\hline & 7 & 0.69 def & $0.086^{b}$ & $0.058^{g}$ & 0.701 ef & $38.01^{\text {cdef }}$ \\
\hline & 8 & 0.67 def & $0.088^{b}$ & $0.098^{a}$ & $0.682^{f}$ & $37.76^{\text {cdef }}$ \\
\hline & 9 & 0.57 ef & $0.064^{f}$ & $0.089^{c}$ & $0.735^{c d}$ & $45.13^{a}$ \\
\hline & 10 & $0.75^{\text {cde }}$ & $0.067^{\mathrm{e}}$ & $0.068^{\mathrm{e}}$ & $0.547^{\mathrm{ij}}$ & 35.89 efg \\
\hline
\end{tabular}

Abbreviations: $\mathrm{Na}$, sodium; K, potassium; POD, peroxidase; PPO, polyphenol oxidase; FC, filed capacity.

*For each column, the values followed by the same letters are not significantly different at $P \leq 0.01$ according to the least significant difference test. 
activities were significantly affected by the drought stress depending on the $M$. peregrina population. The highest POD activity was found in population number $1(0.092$

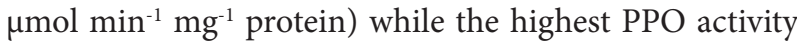
was related to population number $8\left(0.098 \mu \mathrm{mol} \mathrm{min}{ }^{-1}\right.$ $\mathrm{mg}^{-1}$ protein). The POD and PPO activities represented a similar pattern in response to the drought stress (Figures 2 and 3). In other words, drought stress significantly enhanced enzymes activities in $\mathrm{ZnO}-\mathrm{NPs}$ treated and untreated plants. Number 8 and 10 populations had the highest percentage of PPO changes under the drought stress.

Furthermore, proline content significantly increased in all the $M$. peregrina populations under the drought stress. The results indicated that the highest proline content was obtained in population number $3\left(0.843 \mu \mathrm{mol} \mathrm{g}{ }^{-1} \mathrm{FW}\right)$. Moreover, drought stress significantly $(P \leq 0.01)$ increased proline content in untreated plants. Population number 3 had the highest percentage of proline changes under the drought stress.

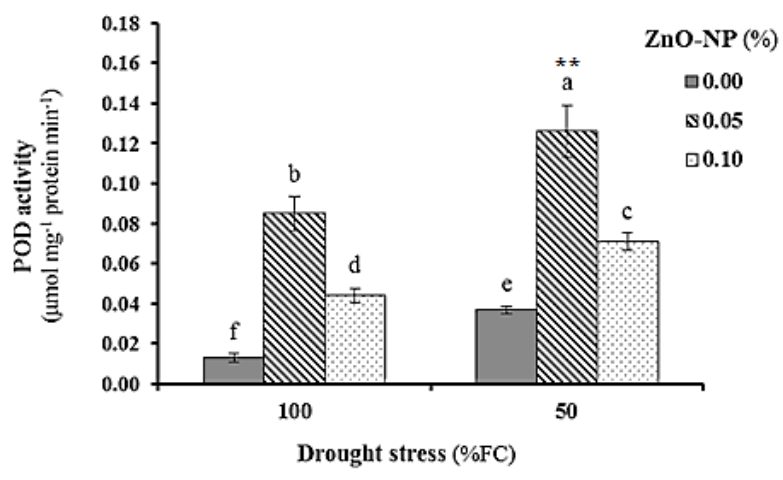

Figure 2. Changes of POD Enzyme Activity Related to the Moringa peregrina Under Well-Watered (100\% FC) and Drought Stress (50\% FC) in Response to ZnO-NP Treatments. The values are provided as the means $(n=3) \pm$ standard errors and different letters demonstrate a significant difference $(P \leq 0.01)$ based on the LSD test.

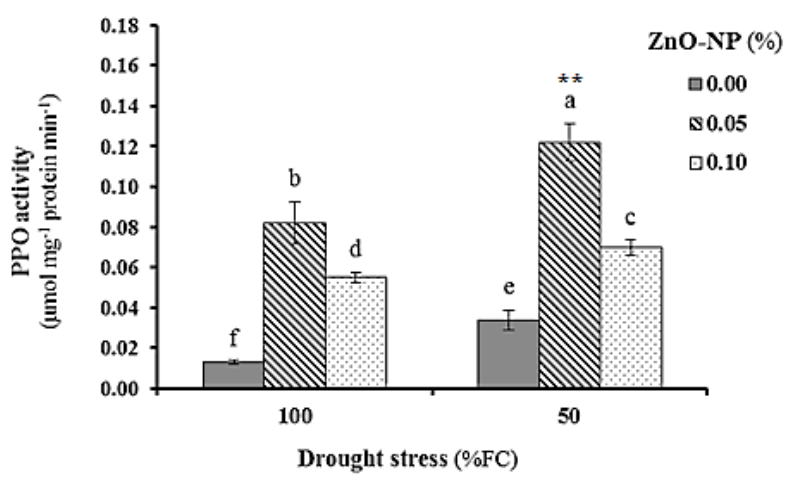

Figure 3. Changes of PPO Enzyme Activity Related to the Moringa peregrina Under Well-Watered (100\% FC) and Drought Stress $(50 \%$ FC) in Response to ZnO-NP Treatments. The values are provided as the means $(n=3) \pm$ standard errors and different letters demonstrate a significant difference $(P \leq 0.01)$ based on the LSD test.
Populations 9 and 2 had the highest carbohydrates content (45.13 and $44.15 \mu \mathrm{g} \mathrm{g} \mathrm{g}^{-1} \mathrm{FW}$, respectively). Additionally, under the drought stress, carbohydrates content significantly reduced in the control plants. As regards the drought stress, population number 2 had the highest percentage changes of carbohydrates content.

\section{ZnO-NP Treatments Induced Responses}

As the results demonstrate, $\mathrm{ZnO}$-NPs treated plants had a higher $\mathrm{Na} / \mathrm{K}$ ratio compared to the untreated plants. Populations 1 (at $0.05 \% \mathrm{ZnO}-\mathrm{NPs}$ ) and 4 (at $0.10 \% \mathrm{ZnO}$ NPs), among the evaluated populations, had the highest $\mathrm{Na} / \mathrm{K}$ ratio (Table 3 ).

Further, the results revealed that POD and PPO activities significantly increased by foliar use of the $\mathrm{ZnO}$ NPs under both well-watered and drought stress since $0.05 \% \mathrm{ZnO}-\mathrm{NP}$ treatment was more effective in enhancing the enzymes activities. The highest POD activity, among others, was found in populations 4 and 1 at $0.05 \% \mathrm{ZnO}$ NP treatment. Furthermore, populations 4 and 8 at $0.05 \%$ $\mathrm{ZnO}-\mathrm{NPs}$ demonstrated the highest PPO activity as compared to the other populations. Moreover, in response to $\mathrm{ZnO}-\mathrm{NP}$ treatments, the highest percentage of POD changes were observed in population number 4 at $0.05 \%$ $\mathrm{ZnO}-\mathrm{NPs}$ while the population number 3 represented the highest percentage of PPO changes at $0.05 \% \mathrm{ZnO}-\mathrm{NPs}$.

Additionally, $\mathrm{ZnO}-\mathrm{NP}$ treatments significantly $(P \leq$ 0.01 ) increased the proline content under both wellwatered and drought stress conditions (Figure 4). Among the $\mathrm{ZnO}$-NPs treated plants, the dose of $0.05 \%$ $\mathrm{ZnO}-\mathrm{NPs}$ was more effective to enhance the content of proline compared to that of the $0.10 \%$ since $M$. peregrina populations had the highest proline content under $50 \%$ FC conditions treating with $0.05 \% \mathrm{ZnO}-\mathrm{NPs}(1.16 \mu \mathrm{mol}$ $\left.\mathrm{g}^{-1} \mathrm{FW}\right)$. In addition, population number 3 at $0.05 \% \mathrm{ZnO}$ NP treatment had the highest proline content among the other populations. Further, in response to $\mathrm{ZnO}-\mathrm{NP}$ treatments, the highest percentage of proline changes were obtained in population number 3 at $0.05 \% \mathrm{ZnO}-\mathrm{NP}$ treatment (Table 4).

Similarly, the results revealed that under both wellwatered and drought stress conditions, carbohydrates content significantly $(P \leq 0.01)$ increased in response to $\mathrm{ZnO}-\mathrm{NP}$ treatment (Figure 5). Furthermore, $0.05 \%$ $\mathrm{ZnO}-\mathrm{NPs}$, among the $\mathrm{ZnO}-\mathrm{NPs}$ treated plants, was more effective in enhancing the carbohydrates content as compared to the $0.1 \% \mathrm{ZnO}-\mathrm{NPs}$. Populations 9 and 2 at $0.05 \% \mathrm{ZnO}-\mathrm{NP}$ treatments demonstrated the highest carbohydrates content as compared to the others. Under $\mathrm{ZnO}-\mathrm{NP}$ treatments, the highest percentage changes related to the carbohydrates content were found in population number 7 as compared to other populations.

\section{Discussion}

The results demonstrated that $\mathrm{Na}^{+} / \mathrm{K}^{+}$ratio significantly decreased in control plants under drought stress, which is 
Table 3. Changes of Some Biochemical Features in Different Moringa peregrina Populations in Response to ZnO-NP Treatments

\begin{tabular}{|c|c|c|c|c|c|c|}
\hline $\begin{array}{l}\text { ZnO-NP } \\
\text { Treatments }\end{array}$ & Populations & $\mathrm{Na} / \mathrm{K}$ & $\begin{array}{c}\text { POD Activity } \\
\text { ( } \mu \mathrm{mol} \mathrm{min}^{-1} \mathrm{mg}^{-1} \text { protein) }\end{array}$ & $\begin{array}{c}\text { PPO Activity } \\
\left(\mu \mathrm{mol} \mathrm{min}^{-1} \mathrm{mg}^{-1} \text { protein }\right)\end{array}$ & $\begin{array}{c}\text { Proline } \\
\left(\mu \mathrm{mol} \mathrm{g}^{-1} \mathrm{FW}\right)\end{array}$ & $\begin{array}{c}\text { Carbohydrates } \\
\left(\mu g^{-1} \text { FW) }\right.\end{array}$ \\
\hline \multirow{10}{*}{$0.00 \%$} & 1 & $0.08^{c-i^{*}}$ & $0.039^{n}$ & $0.026^{\mathrm{kl}}$ & $0.033^{\mathrm{Imn}}$ & $16.93^{i}$ \\
\hline & 2 & $0.08^{c-i}$ & $0.026^{\mathrm{pqr}}$ & $0.022^{\mathrm{m}}$ & $0.039^{\prime}$ & $17.85^{j}$ \\
\hline & 3 & $0.05^{\mathrm{ij}}$ & $0.021 \mathrm{r}$ & $0.021^{\mathrm{m}}$ & $0.025^{p}$ & $17.03^{i}$ \\
\hline & 4 & $0.07^{c-j}$ & $0.013 \mathrm{~s}$ & $0.035^{\mathrm{jk}}$ & $0.032^{\mathrm{Imn}}$ & $16.19^{j}$ \\
\hline & 5 & $0.07^{c-j}$ & $0.034^{\circ p}$ & $0.024 \mathrm{~lm}$ & 0.028 nо & $19.46^{i}$ \\
\hline & 6 & $0.07^{\mathrm{c-j}}$ & $0.025^{\mathrm{pq}}$ & $0.022^{m}$ & $0.038^{\prime}$ & $16.37^{j}$ \\
\hline & 7 & $0.07^{c-j}$ & 0.023 qr & $0.024^{\mathrm{Im}}$ & $0.026^{\text {op }}$ & $16.04^{j}$ \\
\hline & 8 & $0.06^{f-j}$ & $0.036^{\text {no }}$ & $0.038^{i}$ & $0.035^{\mathrm{Im}}$ & $19.52^{j}$ \\
\hline & 9 & $0.06^{\mathrm{f}-\mathrm{j}}$ & $0.038^{j}$ & $0.024^{\mathrm{Im}}$ & $0.029 \mathrm{mn}$ & $18.26^{i}$ \\
\hline & 10 & $0.07^{c-j}$ & $0.039^{\mathrm{j}}$ & $0.024^{\mathrm{Im}}$ & $0.026^{o p}$ & $15.97^{\mathrm{i}}$ \\
\hline \multirow{10}{*}{$0.05 \%$} & 1 & $0.11^{\mathrm{a}}$ & $0.129^{a}$ & $0.074^{f}$ & $0.107^{d}$ & $53.82^{f}$ \\
\hline & 2 & $0.06^{g-j}$ & $0.114^{c}$ & $0.103^{d}$ & $0.118 \mathrm{bc}$ & $67.04^{a b}$ \\
\hline & 3 & $0.09^{\text {b-e }}$ & $0.083^{e}$ & $0.116^{c}$ & $0.129^{a}$ & 54.84 ef \\
\hline & 4 & $0.09^{\text {b-e }}$ & $0.131^{a}$ & $0.139^{a}$ & $0.124^{b}$ & $62.56^{c}$ \\
\hline & 5 & $0.06^{g-j}$ & 0.087 de & $0.086^{e}$ & $0.115^{c}$ & $63.67 b c$ \\
\hline & 6 & $0.06^{g-j}$ & $0.078^{g}$ & $0.104^{d}$ & $0.124^{b}$ & $61.88^{c d}$ \\
\hline & 7 & $0.06^{g-j}$ & $0.121^{b}$ & $0.083^{f}$ & $0.104^{\mathrm{e}}$ & $62.93^{c}$ \\
\hline & 8 & $0.08^{c-i}$ & $0.110^{d}$ & $0.128^{a b}$ & $0.108^{d}$ & $61.50^{c d}$ \\
\hline & 9 & $0.07^{c-j}$ & $0.080^{f}$ & $0.124 b$ & $0.114^{c}$ & $68.91^{a}$ \\
\hline & 10 & $0.06^{\mathrm{g}-\mathrm{j}}$ & $0.080^{f}$ & $0.083 \mathrm{f}$ & $0.096^{f}$ & 58.57 de \\
\hline \multirow{10}{*}{$0.01 \%$} & 1 & $0.10^{b}$ & $0.067^{h}$ & $0.054^{i}$ & $0.069 \mathrm{gh}$ & $33.84^{i}$ \\
\hline & 2 & $0.05^{\mathrm{ij}}$ & $0.076^{g}$ & $0.053^{i}$ & $0.056^{i}$ & $37.80^{h}$ \\
\hline & 3 & $0.08^{c-i}$ & $0.050^{\mathrm{Im}}$ & $0.068^{h}$ & $0.062^{i}$ & $33.38^{i}$ \\
\hline & 4 & $0.11^{\mathrm{a}}$ & $0.058^{j}$ & $0.072 \mathrm{gh}$ & 0.061 & 31.82 i \\
\hline & 5 & $0.09^{\mathrm{b}-\mathrm{e}}$ & $0.057^{j}$ & $0.053^{i}$ & $0.073^{g}$ & $49.06^{\mathrm{gh}}$ \\
\hline & 6 & $0.06^{g-j}$ & $0.046^{\mathrm{m}}$ & $0.053^{i}$ & 0.065 hi & $41.73^{\mathrm{g}}$ \\
\hline & 7 & $0.07^{c-j}$ & $0.063^{i}$ & $0.054^{i}$ & $0.074^{g}$ & $31.38^{i}$ \\
\hline & 8 & $0.07^{c-j}$ & $0.075^{g}$ & $0.075^{g}$ & $0.055^{j}$ & $33.80^{i}$ \\
\hline & 9 & $0.06^{g-j}$ & $0.054 \mathrm{jk}$ & $0.069^{h}$ & $0.073^{g}$ & $48.95 \mathrm{gh}$ \\
\hline & 10 & $0.06^{g-j}$ & $0.052 \mathrm{kl}$ & $0.060^{i}$ & $0.046^{k}$ & $32.67^{i}$ \\
\hline
\end{tabular}

Abbreviations: Na, sodium; K, potassium; POD, peroxidase; PPO, polyphenol oxidase; ZnO-NPs: Zinc oxide nanoparticles.

*For each column, the values followed by the same letters are not significantly different at $P \leq 0.01$ according to the least significant difference test.

in line with the findings of El-Gendy et $\mathrm{al}^{26}$ and Talebi et al. ${ }^{27}$ The reduction in $\mathrm{Na}^{+} / \mathrm{K}^{+}$ratio is due to a decrease or increase in $\mathrm{Na}^{+}$or $\mathrm{K}^{+}$concentrations, respectively. Talebi et $\mathrm{a}^{27}$ reported significantly reduced $\mathrm{Na}$ while increased $\mathrm{K}$ uptakes (correlated with the ion uptake efficiency) in different chickpea (Cicer arietinum) species under drought stress. ${ }^{27}$

The mechanisms by which the drought stress inhibits the mineral uptake in plants were previously suggested. This inhibition is probably promoted by limiting the root growth and nutrient mobility in the soil. Moreover, the total nutrient and mineral uptakes and concentrations are reduced in crops encountered with the drought stress. ${ }^{28}$ Similarly, such reduced absorption of the nutrients is possibly due to the defects in nutrient uptake and unloading mechanisms, as well as reduced transpiration flow under this condition. ${ }^{29}$

Additionally, the findings of the current study regarding changes in nutrient balance in response to the Zn-NPs spray corroborate with those of the Soliman et al who reported that foliar use of Zn-NPs significantly improved mineral nutrient content in $M$. peregrina. ${ }^{30}$

The plant responses to abiotic stresses depend on various factors such as the involved species, the metabolic rate of the plant, and intensity and duration of the stress. ${ }^{7,10}$ Drought stress induces free radicals and ROS leads to alternations in physiological and biochemical properties such as growth, protein degradation, and 


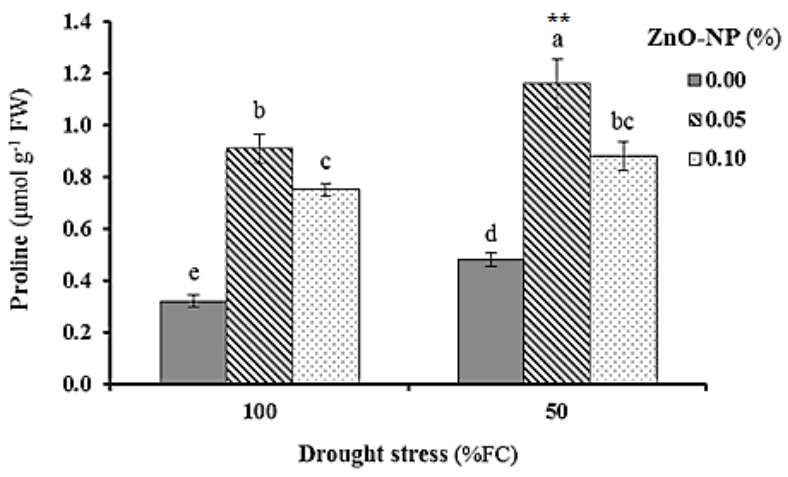

Figure 4. Changes of Proline Content in the Moringa peregrina Under Well-Watered (100\% FC) and Drought Stress (50\% FC) in Response to $\mathrm{ZnO}-\mathrm{NP}$ Treatments. The values are provided as the means $(\mathrm{n}=3) \pm$ standard errors and different letters demonstrate a significant difference $(P \leq 0.01)$ based on the LSD test.

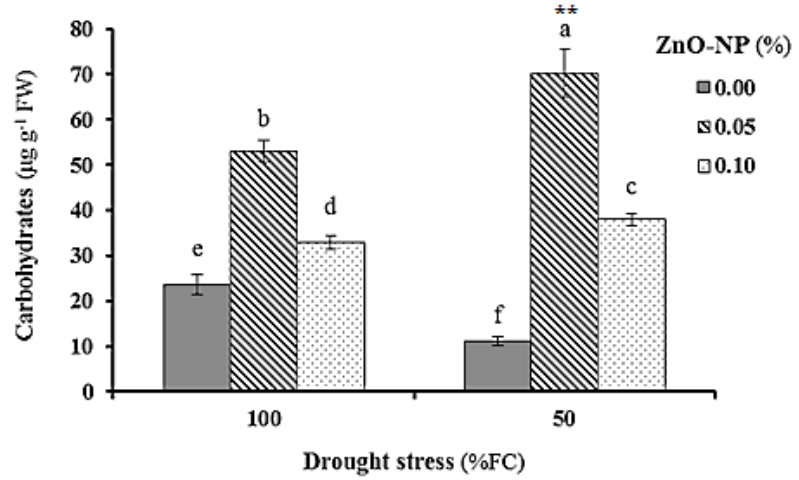

Figure 5. Changes of carbohydrates Content in the Moringa peregrina Under Well-Watered (100\% FC) and Drought Stress (50\% FC) in Response to $\mathrm{ZnO}-\mathrm{NP}$ Treatments. The values are provided as the means $(\mathrm{n}=3) \pm$ standard errors and different letters demonstrate a significant difference $(P \leq 0.01)$ based on the LSD test.

Table 4. The Percentage Changes of Some Biochemistry Traits in 10 Moringa peregrina Populations Compared to the Control Conditions in Response to Drought Stress and Different Concentrations of ZnO-NP Treatments

\begin{tabular}{|c|c|c|c|c|c|c|}
\hline & Populations & $\mathrm{Na} / \mathrm{K}$ & POD Activity & PPO Activity & Proline & Carbohydrates \\
\hline \multicolumn{7}{|c|}{ Drought Stress } \\
\hline \multirow{10}{*}{$\begin{array}{c}50 \% \\
\text { FC }\end{array}$} & 1 & 14.44 & 70.37 & 58.97 & 17.22 & 8.58 \\
\hline & 2 & -7.46 & 58.49 & 47.83 & 25.00 & 17.30 \\
\hline & 3 & -5.19 & 40.48 & 44.23 & 63.37 & 16.14 \\
\hline & 4 & 5.62 & 37.04 & 80.77 & 49.40 & 7.10 \\
\hline & 5 & -34.07 & 71.79 & 47.62 & 31.44 & 12.28 \\
\hline & 6 & 14.75 & 45.95 & 44.68 & 25.90 & 3.90 \\
\hline & 7 & 4.55 & 82.98 & 34.88 & 34.03 & 7.07 \\
\hline & 8 & -9.46 & 76.00 & 96.00 & 29.41 & -3.01 \\
\hline & 9 & -18.57 & 60.00 & 81.63 & 18.93 & 16.28 \\
\hline & 10 & 41.51 & 81.08 & 94.29 & 26.33 & 0.62 \\
\hline \multicolumn{7}{|c|}{ ZnO-NP Treatments } \\
\hline \multirow{10}{*}{$0.05 \%$} & 1 & 37.50 & 230.77 & 184.62 & 224.24 & 217.90 \\
\hline & 2 & -25.00 & 338.46 & 368.18 & 202.56 & 275.57 \\
\hline & 3 & 80.00 & 295.24 & 452.38 & 416.00 & 222.02 \\
\hline & 4 & 28.57 & 907.69 & 297.14 & 287.50 & 286.41 \\
\hline & 5 & -14.29 & 155.88 & 258.33 & 310.71 & 227.18 \\
\hline & 6 & -14.29 & 212.00 & 372.73 & 226.32 & 278.01 \\
\hline & 7 & -14.29 & 426.09 & 245.83 & 300.00 & 292.33 \\
\hline & 8 & 33.33 & 205.56 & 236.84 & 208.57 & 215.06 \\
\hline & 9 & 16.67 & 110.53 & 416.67 & 293.10 & 277.38 \\
\hline & 10 & -14.29 & 105.13 & 245.83 & 269.23 & 266.75 \\
\hline \multirow{10}{*}{$0.10 \%$} & 1 & 25.00 & 71.79 & 107.69 & 109.09 & 99.88 \\
\hline & 2 & -37.50 & 192.31 & 140.91 & 43.59 & 111.76 \\
\hline & 3 & 60.00 & 138.10 & 223.81 & 148.00 & 96.01 \\
\hline & 4 & 57.14 & 346.15 & 105.71 & 90.63 & 96.54 \\
\hline & 5 & 28.57 & 67.65 & 120.83 & 160.71 & 152.11 \\
\hline & 6 & -14.29 & 84.00 & 140.91 & 71.05 & 154.92 \\
\hline & 7 & 0.00 & 173.91 & 125.00 & 184.62 & 95.64 \\
\hline & 8 & 16.67 & 108.33 & 97.37 & 57.14 & 73.16 \\
\hline & 9 & 0.00 & 42.11 & 187.50 & 151.72 & 168.07 \\
\hline & 10 & -14.29 & 33.33 & 150.00 & 76.92 & 104.57 \\
\hline
\end{tabular}

Abbreviations: Na, sodium; K, potassium; POD, peroxidase; PPO, polyphenol oxidase; ZnO-NPs: zinc oxide nanoparticles; FC, field capacity. 
lipid peroxidation. Plants augment the antioxidant systems including both non-enzymatic and enzymatic antioxidants such as the POD and PPO in order to cope with the ROS. ${ }^{31}$

The results regarding the enhanced PPO and POD activities by $\mathrm{ZnO}-\mathrm{NPs}$ are in conformity with the findings of Kheirizadeh Arough et $\mathrm{al}^{32}$ who found that 0.4 and 0.8 $\mathrm{g} \mathrm{L}^{-1} \mathrm{ZnO}-\mathrm{NPs}$ significantly increased the activities of antioxidant enzymes such as PPO and POD in Triticale plants under abiotic stress.

Zinc can act as a stabilizing and protective factor for bio-membranes by binding to membrane proteins. ${ }^{33}$ In addition, zinc ions can bind to ligands such as sulfur, nitrogen, and oxygen, and therefore alleviate oxidative stress. The balance, production, and removal of the oxidative agents are the main factors in determining the cellular fate. Therefore, Zn-NPs may have survival benefits by scavenging the ROS and boosting the antioxidant systems in plants. ${ }^{33}$

Proline functions as the osmolyte, ROS scavenger, as well as the regulator of the redox potential and intracellular $\mathrm{pH}$. Further, it contributes to the stabilization of protein structures Furthermore, proline is essential for the activity of the pentose phosphate pathway which generates the cellular redox potency needed for maintaining many antioxidants in their reduced state. Similarly, it prevents the oxidative photo-damage removing and/or reducing the production of $\mathrm{O}_{2}$ radicals in thylakoid membranes. ${ }^{34}$

The synthesis, storage, and catabolism of proline are considered as highly regulated processes in the plants. Accumulation of large quantities of proline represents that the plants adapt to various biotic and abiotic conditions. Proline is accumulated in plants in response to abiotic stress which is related to its increased production or decreased degradation. ${ }^{35}$ Studies reported that drought stress induced the proline catabolizing enzymes such as proline dehydrogenase (pro-DH) and proline biosynthetic enzymes like glutamate dehydrogenase (GDH), pyrroline5-carboxylate synthetase (P5CS), and pyrroline-5carboxylate reductase (P5CR). ${ }^{36-38}$

Altered carbohydrate content is one of the important characteristics of the stress conditions meddling with processes like photosynthesis, transportation, and respiration..$^{39,40}$ Moreover, an important osmoregulatory role is noted for soluble carbohydrates in the plants. Carbohydrates further augment the ROS removal and protection of biomolecules under the drought stress. They are necessary for the synthesis of phenolic compounds as secondary messengers in plant adaptative responses under drought and other environmental stimuli. Carbohydrate content of the plants is regulated by the rate of photosynthesis, as well as polysaccharides hydrolysis and cellular export under drought stress therefore may demonstrate either increased or decreased carbohydrate pool which is determined by the extent of the carbohydrate deranged metabolism. ${ }^{14}$
Additionally, drought stress can lead to cell death in part by decreasing the content of the carbohydrates. ${ }^{41}$ This may be partly related to the impacts of drought stress on plant physiological processes including reduced photosynthesis which are due to the stomatal constriction, increased metabolic demand for carbohydrates, elevated carbohydrates metabolization, and finally shrinkage of the carbohydrates storages leading to carbon depletion. ${ }^{42}$

The findings are concurrent with those of Mansour et $\mathrm{al}^{43}$ who indicated that foliar application of $\mathrm{Zn}(100 \mathrm{ppm})$ significantly enhanced the total soluble carbohydrates in soybean plants. In addition, El Habbasha et $\mathrm{al}^{44}$ reported that the carbohydrates content of different wheat populations increased in response to foliar use of 100 and $200 \mathrm{~g} \mathrm{Zn} \mathrm{ha}^{-1}$.

The positive effect of $\mathrm{Zn}$ foliar use on total carbohydrates content is probably related to the role of $\mathrm{Zn}$ in regulating the key enzymes of the carbohydrate metabolism. ${ }^{43,45}$ It was further pinpointed that the activity of carbonic anhydrase is reduced in conditions of $\mathrm{Zn}$ deficiency. This enzyme contains $\mathrm{Zn}$ in its structure and is located within the cytosol and chloroplasts. Therefore, carbonic anhydrase can particularly modulate the photosynthesis rate by facilitating the $\mathrm{CO}_{2} / \mathrm{HCO}_{3}{ }^{-}$transportation. ${ }^{46}$

\section{Conclusion}

Generally, an increment was observed in antioxidant enzyme activities and osmoprotectants content under both well-watered (100\% FC) and drought stress (50\% FC) conditions in $M$. peregrina plants sprayed with $0.05 \% \mathrm{ZnO}-\mathrm{NPs}$. This indicates that $0.05 \% \mathrm{ZnO}-\mathrm{NPs}$ could enhance drought tolerance of the plants either in unstressed or stressed conditions. Such information helps further understand the substantial role of the antioxidant defense mechanisms against the drought stress in $M$. peregrina.

\section{Ethical Approval \\ Not applicable.}

\section{Competing Interest}

There are no competing interests to declare.

\section{Acknowledgment}

The authors would like to thank the Islamic Azad University of Tehran (the Science and Research Branch) and the University of Zabol for their financial support.

\section{References}

1. Salehi M, MajnunHoseini N, NaghdiBadi H, Mazaheri D. Biochemical and growth responses of Moringa peregrina (Forssk.) Fiori to different sources and levels of salinity. J Med Plant. 2012;11(43):54-61.

2. Salaheldeen M, Aroua MK, Mariod AA, Cheng SF, Abdelrahman MA. An evaluation of Moringa peregrina seeds as a source for bio-fuel. Ind Crop Prod. 2014;61:49- 
61. doi:10.1016/j.indcrop.2014.06.027

3. Salehi A, Tasdighi H, Gholamhoseini M. Evaluation of proline, chlorophyll, soluble sugar content and uptake of nutrients in the German chamomile (Matricaria chamomilla L.) under drought stress and organic fertilizer treatments. Asian Pac J Trop Biomed. 2016;6(10):886-891. doi:10.1016/j.apjtb.2016.08.009

4. Soliman AS, El-feky SA, Darwish E. Alleviation of salt stress on Moringa peregrina using foliar application of nanofertilizers. J Hortic Forest. 2015;7(2):36-47. doi: $10.5897 /$ jhf2014.0379

5. Xiaolu W, Jie Y, Aoxue L, Yu C, Yijun F. Drought stress and re-watering increase secondary metabolites and enzyme activity in dendrobium moniliforme. Ind Crop Prod. 2016;94:385-393. doi:10.1016/j.indcrop.2016.08.041

6. Wang R, Gao M, Ji S, Wang S, Meng Y, Zhou Z. Carbon allocation, osmotic adjustment, antioxidant capacity and growth in cotton under long-term soil drought during flowering and boll-forming period. Plant Physiol Biochem. 2016;107:137-146. doi:10.1016/j.plaphy.2016.05.035

7. Jeena GS, Phukan UJ, Shukla RK. Drought-tolerant plants. In: Dubey SK, Pandey A, Sangwan RS, eds. Current Developments in Biotechnology and Bioengineering: Crop Modification, Nutrition, and Food Production. 2017:101123. doi:10.1016/B978-0-444-63661-4.00005-0

8. Vardhini BV, Anjum NA. Brassinosteroids make plant life easier under abiotic stresses mainly by modulating major components of antioxidant defense system. Front Environ Sci. 2015;2:67. 2:1-16. doi:10.3389/fenvs.2014.00067

9. Weisany W, Sohrabi Y, Heidari G, Siosemardeh A, Ghassemi-Golezani K. Changes in antioxidant enzymes activity and plant performance by salinity stress and zinc application in soybean (Glycine max L.). Plant Omics J. 2012;5(2):60-67.

10. Fini A, Guidi L, Ferrini F, et al. Drought stress has contrasting effects on antioxidant enzymes activity and phenylpropanoid biosynthesis in Fraxinus ornus leaves: An excess light stress affair? J Plant Physiol. 2012;169:929-939. doi:10.1016/j.jplph.2012.02.014

11. Nazar R, Umar S, Khan NA, Sareer O. Salicylic acid supplementation improves photosynthesis and growth in mustard through changes in proline accumulation and ethylene formation under drought stress. South Afr J Bot. 2015;98:84-94. doi:10.1016/j.sajb.2015.02.005

12. Sun J, Gu J, Zeng J, et al. Changes in leaf morphology, antioxidant activity and photosynthesis capacity in two different drought-tolerant cultivars of chrysanthemum during and after water stress. Sci Hortic. 2013;161:249-258. doi:10.1016/j.scienta.2013.07.015

13. Muller T, Lentzsch P, Muller MEH. Carbohydrate dynamics in leaves of rapeseed (Brassica napus) under drought. J Agron Crop Sci. 2012;198(3):207-217. doi:10.1111/j.1439037x.2011.00502.x

14. Hura T, Dziurka M, Hura K, Ostrowska A, Dziurka K. Different allocation of carbohydrates and phenolics in dehydrated leaves of triticale. J Plant Physiol. 2016;202:1-9. doi:10.1016/j.jplph.2016.06.018

15. Seghatoleslami M, Forutani R. Yield and water use efficiency of sunflower as affected by nano $\mathrm{ZnO}$ and water stress. J Adv Agric Technol. 2015;2(1):34-37. doi:10.12720/ joaat.2.1.34-37

16. Laware SL, Raskar S. Influence of zinc oxide nanoparticles on growth, flowering and seed productivity in onion. Int J Curr Microbiol App Sci. 2014;3(7):874-881.

17. Torabian S, Zahedi M, Khoshgoftarmanesh A. Effect of foliar spray of zinc oxide on some antioxidant enzymes activity of sunflower under salt stress. J Agric Sci Technol. 2016;18:1013-1025.

18. Karami S, ModarresSanavy SAM, Ghanehpoor S, Keshavarz H. Effect of foliar zinc application on yield, physiological traits and seed vigor of two soybean cultivars under water deficit. Not Sci Biol, 2016;8(2):181-191. doi:10.15835/ nsb.8.2.9793

19. Swain PS, Rao SBN, Rajendran D, Dominic G, Selvaraju S. Nano zinc, an alternative to conventional zinc as animal feed supplement:A review. Anim Nutr. 2016;2(3):134-141. doi:10.1016/j.aninu.2016.06.003.

20. Kramer P, Boyer JS. Water Relations of Plants and Soils. San Diego, CA, USA: Academic Press; 1995:495.

21. Waling I, Van Vark W, Houba VJG, Van der lee JJ. Soil and plant analysis, a series of syllabi. Part 7. Plant analysis procedures. Wageningen Agriculture University; 1989.

22. Hung KT, Kao CH. Nitric oxide counteracts the senescence of rice leaves induced by abscisic acid. J Plant Physiol. 2003;160 (8):871-879. doi:10.1078/0176-1617-01118

23. Kar M, Mishra D. Catalase, peroxidase, and polyphenoloxidase activities during rice leaf senescence. Plant Physiol. 1976;57(2):315-319. doi:10.1104/pp.57.2.315

24. Bates LS, Waldren, SP, Teare ID. Rapid determination of free proline for water-stress studies. Plant Soil. 1973;39:205207. doi:10.1007/bf00018060

25. Irigoyen JJ, Emerrich DW, Sanchez-Diaz M. Water stress induced changes in concentrations of praline and total soluble sugars in nodulated alfalfa plant. J Physiol Plant. 1992;84(1):55-60. doi:10.1034/j.1399-3054.1992.840109.x

26. El-Gendy SA, Abd Elmoniem EM, Al-Abdulla MM, Eisa SS. Morphological and physiological responses of Acacia saligna (Labill.) to water stress. Aust J Basic Appl Sci. 2012;6(4):90-97.

27. Talebi R, Ensafi MH, Baghebani N, Karami E, Mohammadi K. Physiological responses of chickpea (Cicer arietinum) genotypes to drought stress. Environ Exp Biol. 2013;11:915.

28. Gunes A, Cicek N, Inal A, et al. Genotypic response of chickpea (CicerarietinumL.) cultivars to drought stress implemented at pre- and post-anthesis stages and its relations with nutrient uptake and efficiency. Plant Soil Environ. 2006;52(8):368-376. doi:10.17221/3454-pse

29. Garg BK. Nutrient uptake and management under drought:nutrient-moisture interaction. Curr Agric. 2003;27:1-8.

30. Hafeez B, Khanif YM, Saleem M. Role of zinc in plant nutrition-A review. Am J Exp Agric. 2013;3(2):374-391. doi:10.9734/ajea/2013/2746

31. Ahmad P, Jamsheed S, Hameed A, et al. Drought stress induced oxidative damage and antioxidants in plants. In: Ahmad P, ed. Oxidative Damage to Plants. 2014:345-367. doi:10.1016/B978-0-12-799963-0.00011-3

32. KheirizadehArough Y, SeyedSharifi R, Sedghi M, Barmiki M. Effect of zinc and bio fertilizers on antioxidant enzymes 
activity, chlorophyll content, soluble sugars and proline in Triticale under salinity condition. Not Bot Horti Agrobo. 2016;44(1):116-124. doi:10.15835/nbha44110224

33. Zago MP, Oteiza PI. The antioxidant properties of zinc:Interactions with iron and antioxidants. Free Radic Biol Med. 2001;31:266-274. doi:10.1016/s08915849(01)00583-4

34. Hossain MA, Anamul Hoque M, Burritt DJ, Fujita M. Proline protects plants against abiotic oxidative stress: biochemical and molecular mechanisms. In: Ahmad P, ed. Oxidative Damage to Plants. 2014;477-522. doi:10.1016/ B978-0-12-799963-0.00016-2.

35. Oloumi H, Soltaninejad R, Baghizadeh A. The comparative effects of nano and bulk size particles of $\mathrm{CuO}$ and $\mathrm{ZnO}$ on glycyrrhizin and phenolic compounds contents in Glycyrrhiza glabra L. seedlings. Ind J Plant Physiol. 2015;20(2):157. doi:10.1007/s40502-015-0143-X

36. Hayat S, Hayat Q, Alyemeni MN, Wani AS, Pichtel J, Ahmad A. Role of proline under changing environments. A review. Plant Signal Behav. 2012;7(11):1456-1466. doi:10.4161/psb.21949

37. Chaitanya KV, Rasineni GK, Reddy AR. Biochemical responses to drought stress in mulberry (Morusalba L.): evaluation of proline, glycine betaine and abscisic acid accumulation in five cultivars. Acta Physiol Plant. 2009;31(3):437-443. doi:10.1007/s11738-008-0251-6

38. Rao S, Shekhawat GS. Toxicity of $\mathrm{ZnO}$ engineered nanoparticles and evaluation of their effect on growth, metabolism and tissue specific accumulation in Brassica juncea. J Environ Chem Eng. 2014;2(1):105-114. doi: 10.1016/j.jece.2013.11.029

39. Disante KB, Fuentes D, Cortina J. Response to drought of Zn-stressed Quercus suber L. seedlings. Environ Exp Bot.
2011;70:96-103. doi:10.1016/j.envexpbot.2010.08.008

40. Ghorbanli M, Arbabian S, Taghizadeh Z. The effect of zinc excess on antioxidant enzymes, proline and soluble carbohydrates in Plantago major L. Iran J Plant Physiol. 2015;6(1):1551-1556.

41. Piper FI. Drought induces opposite changes in the concentration of non-structural carbohydrates of two evergreen Nothofagus species of differential drought resistance. Ann Forest Sci. 2011;68(2):415-424. doi:10.1007/ s13595-011-0030-1

42. McDowell NG, Allen CD, Marshall L. Growth, carbonisotope discrimination, and drought-associated mortality across a Pinus ponderosa elevational transect. Glob Chang Biol. 2009;16(1):399-415. doi:10.1111/j.13652486.2009.01994.x

43. Mansour MM. Response of soybean plants to exogenously applied with ascorbic acid, zinc sulphate and paclobutrazol. Rep Opin. 2014;6(11):17-25.

44. El Habbasha SF, Badr EA, Abdel Latef E. Effect of zinc foliar application on growth characteristics and grain yield of some wheat varieties under $\mathrm{Zn}$ deficient sandy soil condition. Int J ChemTech Res. 2015;8(6):452-458.

45. Saadati S, Moallemi N, Mortazavi SMH, Seyyednejad SM. Effects of zinc and boron foliar application on soluble carbohydrate and oil contents of three olive cultivars during fruit ripening. Sci Horti. 2013;164:30-34. doi:10.1016/j. scienta.2013.08.033

46. Sawan ZM, Mahmoud MH, El-GuibaliA H. Influence of potassium fertilization and foliar application of zinc and phosphorus on growth, yield components, yield and fiber properties of Egyptian cotton (Gossypiumbar badense L.). J Plant Ecol. 2008;1(4): 259-270. doi: 10.1093/jpe/rtn021 